\title{
Islamic vs. Conventional Banking in Financial Intermediation: What Does the Case of Egypt Show?
}

\author{
Ali Massoud $^{1,2}$ \\ ${ }^{1}$ Professor of Economics at Sohag University, Egypt \\ ${ }^{2}$ Research Fellow at Economics Department, Central European University, Hungary \\ Correspondence: Ali Massoud, Professor of Economics at Sohag University, Egypt.
}

Received: April 24, 2015

doi:10.11114/aef.v2i3.828
Accepted: May 7, 2015

Available online: May 19, 2015

\begin{abstract}
The financial crisis of 2007/2008 illustrated that Islamic banking model is worth to be considered. Many studies have shown that during and after the crisis, Islamic banks were more resilience than conventional banks. In Egypt both types of banks exist which provides a good opportunity to investigate these both models of banking. The purpose of this paper is to examine to what extent are Islamic banks different from conventional banks? In addition to data analysis for the performance and the operations of the two types of banks, I calculated a new index called Intermediation for Development Index (IFDI) introduced by Massoud (forthcoming). The paper concludes that while in theory, Islamic banking provides a plausible alternative for conventional banking, in practice it fails to do so. This failure can be attributed to two factors. First, the high level of operational and liquidity risks that exist in a pure Islamic banking. Second, Islamic banks have failed to provide a wide range of brand new facilities to their customers. Instead, what they are doing is providing the appropriate Islamic terminology for de facto conventional financial operations and products. The calculation of IFDI for a number of Islamic \& conventional banks in Egypt shows that both Islamic banks in the sample preformed less than conventional banks, except for Bank of Alexandria. Thus, for Islamic banking to provide an attractive alternative for conventional banking: (1) Islamic banks should take some measures that make them close to the theory of Islamic banking in banks' operations \& facilities, not just providing Islamic terminology for the existing conventional banking products. (2) Islamic banking experts have to find out solutions for the difficulties that face Islamic banks that implement the pure Islamic banking model. Examples of such difficulties are: operational \& liquidity risks, the competitiveness, and the level of expertise in the Islamic banking industry.
\end{abstract}

Keywords: Islamic banking, Islamic finance, financial intermediation, and banks' performance.

\section{Introduction}

According to the World Islamic Banking Competitiveness Report 2013-2014, the Islamic banking assets with commercial banks globally accumulate for $\$ 1.7$ trillion with an annual growth of $17.6 \%$. Even though Islamic banking has been known since the 1970's, this industry has witnessed a great attention since the global financial crisis of 2007/2008. During this crisis none of the Islamic banks suffered from deposits run. One lesson came out of the global financial crisis that Islamic banks could be more resilient during financial panics. This can be attributed to the specific operations of the Islamic banks. To comply with Sharia, Islamic banks cannot generate profits by lending money and charging interest. Thus, they must look for different types of contracts that are based on partnership with their clients. In order to generate profits, Islamic banks must focus on investments and emphasize the soundness of the projects they finance. This means that their operations focus on capital creation and trade enhancements. Musharka, Mudaraba, and Murabaha are examples of forms of the financial contracts used by Islamic banks. Moreover, Islamic banks are not allowed to engage in risky operations that take place in the forward and future markets. Derivatives are examples of such operations. Moreover, Islamic banks work under the concept of risk sharing. Both profits and losses are shared between the Islamic bank and its clients. Ismail, A., G. et al. (2014) Illustrated that the adaption of risk sharing promotes value creation to the depositors \& shareholder and it would have a large impact on the economy as a whole. In addition to that, Islamic banking have another great aspect which is the ethical and moral values that govern their operations. The above issues formulate the business model of Islamic banking and differentiate it from the business model that the conventional banks follow. 
Given the fact that substantial number of the Muslim countries suffer from high poverty rates, we expect that the financial markets in these countries to be the center of poverty alleviation strategies followed by their national governments. Islamic banks, in theory, can play a vital role in poverty alleviation through providing microfinance for individuals as well as enhancing financial inclusion \& empowerment for the poor. Moreover, Islamic banks can enhance poverty alleviation through providing finance for SMEs. The Murabaha and Musharka contracts are specific products for Islamic banks that enable poor individuals and SMEs to attain the finance they need with better conditions than the forms of contracts provided by conventional banks. The history of conventional banking has shown that these type of banks only concentrate on the ability of their customers to pay regardless the way in which they use the loans. On the opposite side, Islamic banks concentrate on the quality of the projects they finance. By providing assets not cash solve the problem of misusing the fund which caused many insolvency problems. Massoud (2013) concluded that providing loans to the poor using conventional instruments could lead to worsen poverty instead of alleviating it.

In Egypt, both Islamic and conventional banks exist and supervised by the Central Bank of Egypt (CBE). However, for historical reasons the conventional banks dominate the banking industry. The rationale of establishing Islamic banks in Egypt is that a significant portion of the Egyptian population is reluctant to deal with conventional banks because they believe that they are usury-institutions. Since usury is prohibited in Islam, some Egyptians were voluntary excluded from the financial system. Establishing Islamic banks aimed to include these people in the financial system.

Even though, Islamic banking was introduced into the Egyptian financial system from the late of 1970's, by establishing Faisal Islamic Bank, the argument about to what extent Islamic banks, in practice, provide a unique business model is still going on. In theory, Islamic banking provides a reasonable substitute of conventional banking. However, in practice the matter does not appear such so. The importance of this paper comes from its attempt to fill the gap in the literature regarding this issue by examining the functions of both Islamic and conventional banks in the prospective of being financial intermediaries in Egypt. This is a very important issue that literature does not cover appropriately in a way stands along with the growing importance of the Islamic banking model in Egypt and the potential that this model has. The remainder of the paper proceeds as follows. Section (2) is allocated for the literature review. Section (3) summarizes the history of Islamic banking in Egypt. Section (4) provides a comprehensive comparative analysis for Islamic and conventional banks in Egypt. Section (5) presents the calculation of IFDI. Section (6) summarizes the conclusion and policy recommendations.

\section{Literature Review}

Since the global financial crisis erupted in 2007/2008, Islamic banking has been under investigation by many economists. On the one hand, many studies have shown that Islamic banks performed better than conventional banks during this crisis. The strong performance for Islamic banks attributed to the nature of their operations. Islamic banks are interest- free institutions built on profit and loss sharing. Moreover, some ethics and moral aspects of Islamic banking were highlighted as well. On the other hand, some studies have illustrated that Islamic banks operate in ways similar to the ways in which conventional banks operate. According to this view, Islamic banks have been deviated from their expected role as providers of capital to finance new firms, extending the successful firms, and transforming new ideas into projects. Thus, Islamic banking instead of providing a substitute for conventional banking, it is just replicate it under different forms and rules to make their products and operations sharia complaint. This section provides a summary of some studies that compare between Islamic and conventional banking.

Hasan and Dridi (2015) examined to what extent the global financial crisis affected Islamic banks and conventional banks differently. By using data for 120 Islamic and conventional banks covering eight countries: Bahrain, Jordan, Kuwait, Malaysia, Qatar, Saudi Arabia, Turkey, and UAE, the study concluded that Islamic banks performed better than conventional banks during the global financial crisis. In terms of profitability, despite the higher profitability of Islamic banks compared with conventional banks pre-global crisis period (2005-07), their profitability, in average, for the period post the crisis (2008-09) was similar to that of conventional banks. Thus, the study concluded that the high profitability of Islamic banks before the crisis was not a result of excessive risk taking activities. Regarding credit and assets growth, the study found that in both indicators, Islamic banks performed better than conventional banks at least twice during the crisis. In conclusion, Islamic banks were more resilience than conventional banks during the global financial crisis.

Farooq and Zaheer (2015) investigated to what extent the Pakistani Islamic banks affected differently from conventional banks by the financial panics that took place in Pakistan between September 27, 2008 and November 14, 2008. By empirically examining weekly deposit data for all Pakistani banks, the study concluded that the Islamic banks' branches were less prone to deposit withdrawals during the financial panic than conventional banks' branches. The study highlighted that the expansion of Islamic banking may enhance the stability of the banking system as a whole.

Beck, et al. (2013) used a sample of 510 banks across 22 countries covering the period from 1995 to 2009 to examine to what extent Islamic banks are different from conventional banks and to what extent Islamic banks were more resilience 
than conventional banks during the global financial crisis. The study found that Islamic banks performed better during the financial crisis than conventional banks in terms of capitalization and asset quality. However, it highlighted that the way in which Islamic banks operate does not provide a different business model for conventional banking. Thus, Islamic banking has deviated from the core of the Islamic finance principals. Moreover, the study found that Islamic banks are less efficient, but have higher intermediation ratios \& asset quality and they are better capitalized than conventional banks.

Kassim and Abd. Majid (2015) used VAR model to examine the impact of financial shocks on the Islamic banks vis-à-vis conventional banks in Malaysia. They found that both the Islamic and conventional banking systems are vulnerable to financial shocks which means that Islamic financial system is not sheltered from financial shocks.

Khan (2010) examined to what extent do the actual Islamic banking practices live up to the ideal Islamic principles and how different are they from conventional banking? The study concluded that the operations and the products of Islamic banks do not provide a clear substitute to the conventional banking. Instead, what they are doing is providing the appropriate Islamic terminology for de facto conventional financial operations and products.

In addition to the above studies, many other studies examined the difference between Islamic banks and conventional banks from other aspects. For instance, Ariss (2010) investigated the competitiveness of Islamic banks compared with conventional banks. He concluded that Islamic banks are less competitiveness than conventional banks.

\section{The History of Islamic Banking in Egypt}

The first attempt to put Islamic banking on place in the financial system in Egypt was in 1963 by Dr. Elnajar, when he established the Saving Bank in the city of Meit Ghamr in the delta. The bank had extended to nine branches. For political reasons, the bank was shut down and replaced by the Nasser Social Bank. In 1981 the CBE permitted the conventional banks to open Islamic banking branches. Currently, there are three large Islamic banks operating in Egypt, beside a number of Islamic banking's windows in the commercial banks. This section provides a brief summery on the three major Islamic banks in Egypt.

\subsection{Faisal Islamic Bank}

Faisal Islamic bank is the first and the largest Islamic commercial bank in Egypt. The bank officially started his operations on July $5^{\text {th }}, 1979$. Its total assets crossed 48 billion L.E. in December, 2014. The bank operates through 31 branches that cover all Egyptian regions. According to the bank website:

"There was a great demand for the bank's shares at the time of subscription in the Bank's capital. This demand exceeded by five times the shares offered for subscription. This prompted successive increases in the Bank's capital till it reached \$500 million as an authorized capital against \$297 million as an issued and fully paid-up capital. As at 31/12/2012 the bank manages more than one million and fifty Thousand accounts. The bank's total assets reached more than $6 \$$ billion by the end of 2012."

\subsection{Abu Dhabi Islamic Bank-Egypt}

Abu Dhabi Islamic Bank-Egypt was registered under this name at the CBE on April ${ }^{\text {rd }}$, 2013. However, the history of this bank goes back to 1974, when the National Bank for Development (NBD) was established. In 2007, an acquisition of the NDB took place through the Emirati consortium between Abu Dhabi Islamic Bank and Emirates International Investment Company (EIIC). After the acquisition, the bank has been offering a broad spectrum of Sharia-Compliant banking products. At the end of December, 2014, the financial statement of the bank showed that its total assets crossed 19 billion L.E. and it has extended to cover all Egyptian governorates through 70 branches and 40 microfinance units. According the bank website:

"Following the acquisition, the paid-up capital increased almost seven-fold from EGP 281mn to EGP $2 b n$ and EGP 4 bn authorized capital. ADIB Egypt posted EGP 237 mn net profits end of 2014, which represents a 130\% increase compared to the same period of 2013. ADIB Egypt succeeded in establishing a retail and corporate platform to service the customers in different segments and provide the necessary services of short-term and long-term finance. All these measures enabled the Bank to build a broad base portfolio of leading local and international companies operating in the Egyptian market."

\subsection{Al Baraka Egypt Bank}

Al Baraka Egypt Bank started its operations as a commercial bank that provides Sharia-Complaint products in March $19^{\text {th }}, 1980$. According to the last financial statement, its total capital crossed 22 billion L.E. This makes it the second largest Islamic bank in Egypt after Faisal Islamic Bank. The bank operates through its 27 branches that covers all Egyptian regions in addition to its foreign currency exchange offices. According to the bank website:

“... it is worth mentioning that the Bank launches numerous new and unprecedented retail financing programs in the 
Egyptian market that satisfy the requirements of the different brackets of the community, which all conform to the provisions of the tolerant Islamic Shariá; among which are financing private and foreign education, clubs, surgeries and tours in addition to financing cars and real estate finance. It is worth mentioning that all operations of the Bank and its transactions are audited by an independent Shariá supervisory Board. The Bank provides direct financing to companies and institutions that enjoy high credit worthiness, and participates in the syndicated loans of economically feasible large projects that provide large employment opportunities. In continuation to the pioneering role of the Bank as an Islamic banking institution that represents the investment arm in Egypt of Al Baraka Banking Group (the major investor in the Bank), the Bank contributes to the finance of small and medium enterprises which directly contributes to consolidating the national economy. Within this framework, our Bank concluded a contract with the Social Fund for Development to finance new and existing small enterprises by the Islamic partnership system (Mushraka) from the finance granted for the foregoing by the World Bank."

\section{Data Analysis}

This section is allocated to compare the performance of the two largest Islamic Banks in Egypt with other conventional banks classified into four categories: public banks, privatized banks, foreign banks, and specialized banks. In this paper, Faisal Islamic Bank and Abu Dhabi Islamic Bank represent the Islamic banking. For the public banks, the sample includes Banque Misr, Banque Du Caire, and the National Bank of Egypt. Regarding the privatized banks, Bank of Alexandria was used as the only privatized bank. Commercial International Bank (CIB) represents the foreign banks. Finally, the sample includes Export Development Bank of Egypt and the Industrial Development Bank of Egypt as representatives for specialized banks. We did not include the Housing and Development Bank because of the data shortage.

This section employs variety of indicators to assess to what extent are the Islamic Banks in Egypt different from other banks in terms of their role as intermediaries; their business model; and their role in serving the poor regions in Egypt? The remainder of this section is allocated to examine various aspects of both groups of banks by investigating many indicators as follows.

\subsection{The size of Islamic Banks relative to the other Banks in Egypt.}

In order to assess the size of Islamic Banks in Egypt relative to other banks, total assets were used as an indicator of the size of the banks.

Figure (1) shows that based on their total assets, Islamic Banks are relatively small. The total assets for both Islamic Banks account for less than 1/6 of the total assets of the National Bank of Egypt and less than $1 / 2$ of the total assets of the CIB. However, the total assets of Faisal Islamic Bank exceeds both the privatized bank (Bank of Alexandria) and the specialized banks, represented by Export Development Bank \& Industrial Development Bank. Regarding the relative importance of the Islamic Banks used in the sample, Faisal Islamic Bank accumulates assets of 2.5 times of the accumulated assets by Abu Dhabi Islamic Bank. The total assets for these banks are 427.8 and 19.7 billion Egyptian L.E., respectively.

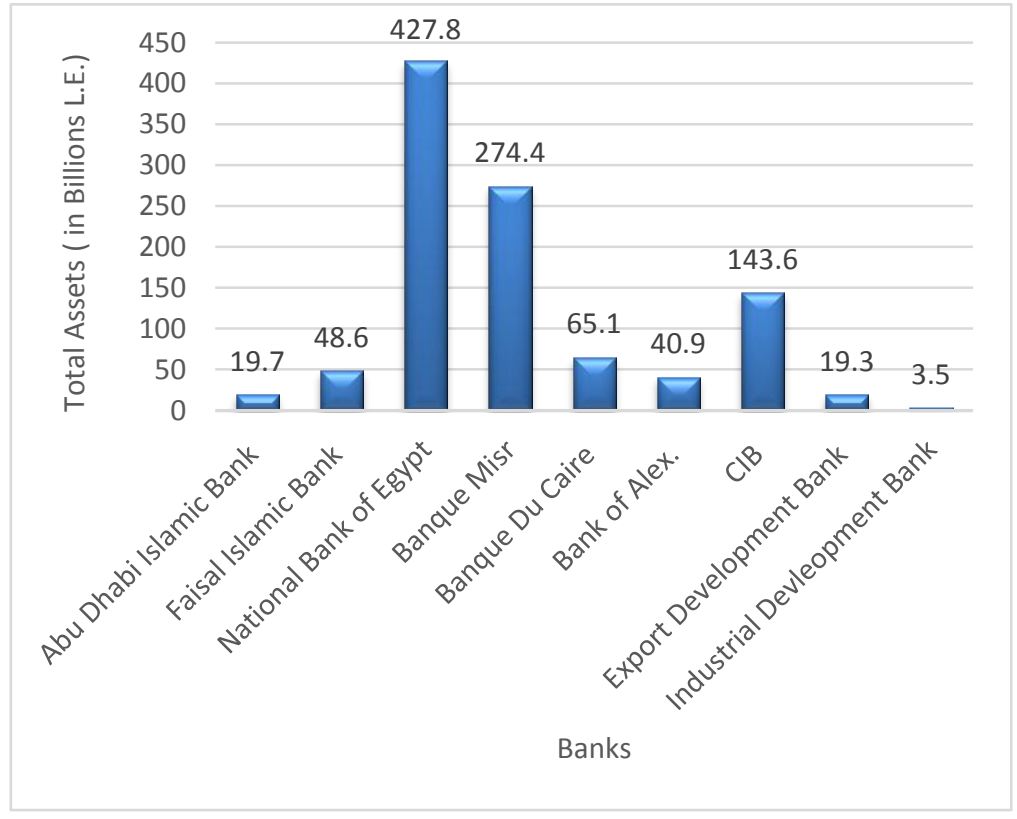

Figure 1. The Total Assets of the Banks 


\subsection{The role of Banks as financial intermediaries in Egypt.}

In order to assess the role of Islamic Banks as financial intermediaries in Egypt in comparison with other banks, the following indicators are used.

First, deposits as a percentage of total liabilities. As shown in figure (2), according to this indicator, Faisal Islamic Banks is ranked the first among other banks in the sample. This reflects the ability of the bank to attract depositors. However, Abu Dhabi Islamic Bank's rank is a little bit behind. Its deposits as a percentage of total liabilities exceeds the one standard deviation below the average of the sample. We notice from figure (2) that deposits as a percentage of total liabilities is very low for the Industrial Development Bank. This low indicator can be attributed to the nature of the bank.

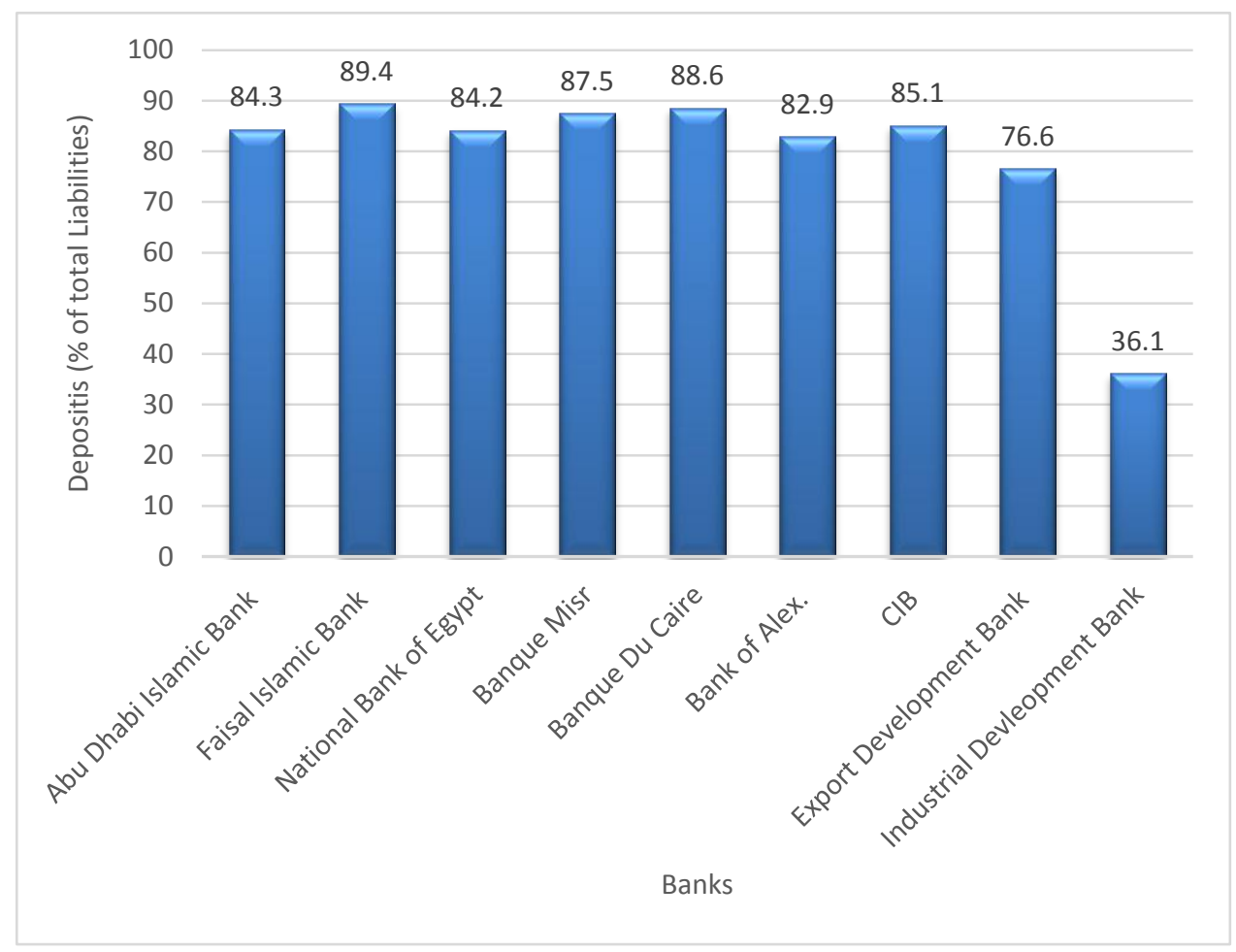

Figure 2. Deposits (\% of the total liabilities)

Second, Financing \& facilities as a percentage of total assets.

The importance of this indicator comes from that it shows to what extent banks prefer to engage in financing activities as financial intermediaries relative to other low risk assets such as: governmental financial instruments. For instance, the more finance and facilities Banks provide relative to treasury bills, the greater the role they play as financial intermediaries. Figure (3) shows that while Abu Dhabi Islamic Bank prefers to engage in financing and other facilities, Faisal Islamic Bank prefers to purchase treasury bills over financing and other facilities. As this figure shows, Abu Dhabi Islamic Bank is ranked the second bank among the commercial banks in terms of the percentage of its finance facilities in respect to its total assets which is $52.1 \%$. Just after Bank of Alexandria in which a percentage of 53.8\% of its assets is used to finance its customers' activities. While the percentage of finance \& facilities of total assets exceeds one standard deviation above the sample average for Abu Dhabi Islamic Bank, it is more than one standard deviation below the sample average for Faisal Islamic Bank. Also, while the percentage of treasury bills of the total assets for Abu Dhabi Islamic Bank is less than the sample average by more than one standard deviation, this percentage exceeds two standard deviation above the sample average for Faisal Islamic Bank. In a matter of fact Faisal Islamic Bank is ranked the first among all commercial banks in the sample in terms of purchasing treasury bills measured by the percentage of treasury bills to the total assets. We notice, surprisingly, that Bank of Alexandria, a specialized bank, has a very high percentage of finance \& facilities to its total assets. Moreover, the Industrial Development Bank does not purchase any treasury bills at all. 


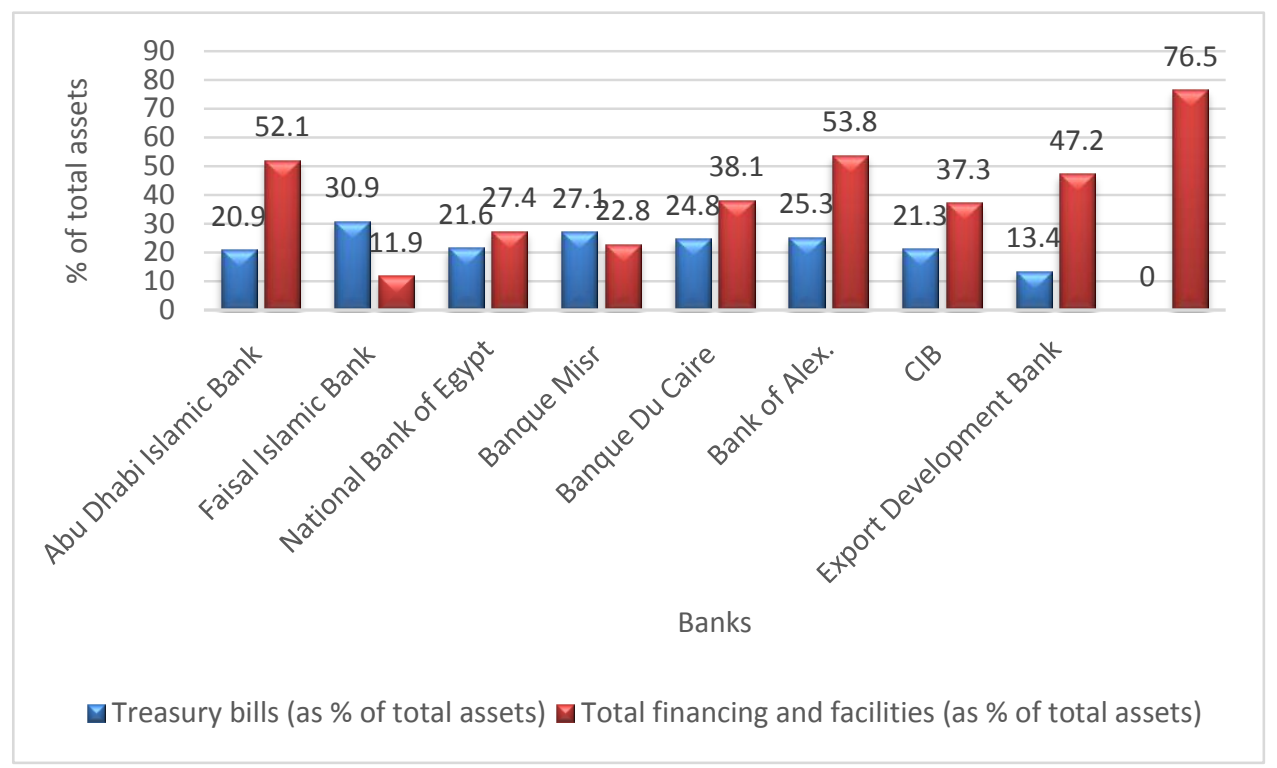

Figure 3. Treasury bills and financing \& and facilities (\% of total assets)

Third, the ratio of total finance \& facilities to deposits.

The importance of this indicator comes from its direct expression of the real meaning of financial intermediation. It simply shows how much finance do the banks provide to their customers who need finance relative to how much their customers who have extra of financial resources deposit money in them? As figure (4) shows, according to this indicator, while Abu Dhabi Islamic Bank is ranked the second among all the commercial banks in the sample, Faisal Islamic Bank is ranked the last. The ratio of total finance \& facilities to deposits in Abu Dhabi Islamic Bank is 0.62:1 which means that out of every 1000 L.E. the bank receives from its customers who have extra financial resources, it provides 620 L.E. as finance \& facilities to its other customers who have a shortage of finance. This ratio is more than two standard deviation above the average of the sample of the commercial banks. For Faisal Islamic Bank, the ratio of finance \& facilities to deposits is $0.13: 1$ which means out of every 1000 L.E. that the bank receives from its customers who have extra financial resources, it provides only 130 L.E. in form of finance and other facilities to its customers who have a shortage in finance. Also, the ratio of finance \& facilities to deposits in Faisal Islamic Bank is very low that it is more than two standard deviation below the average of the sample of the all commercial banks under examination.

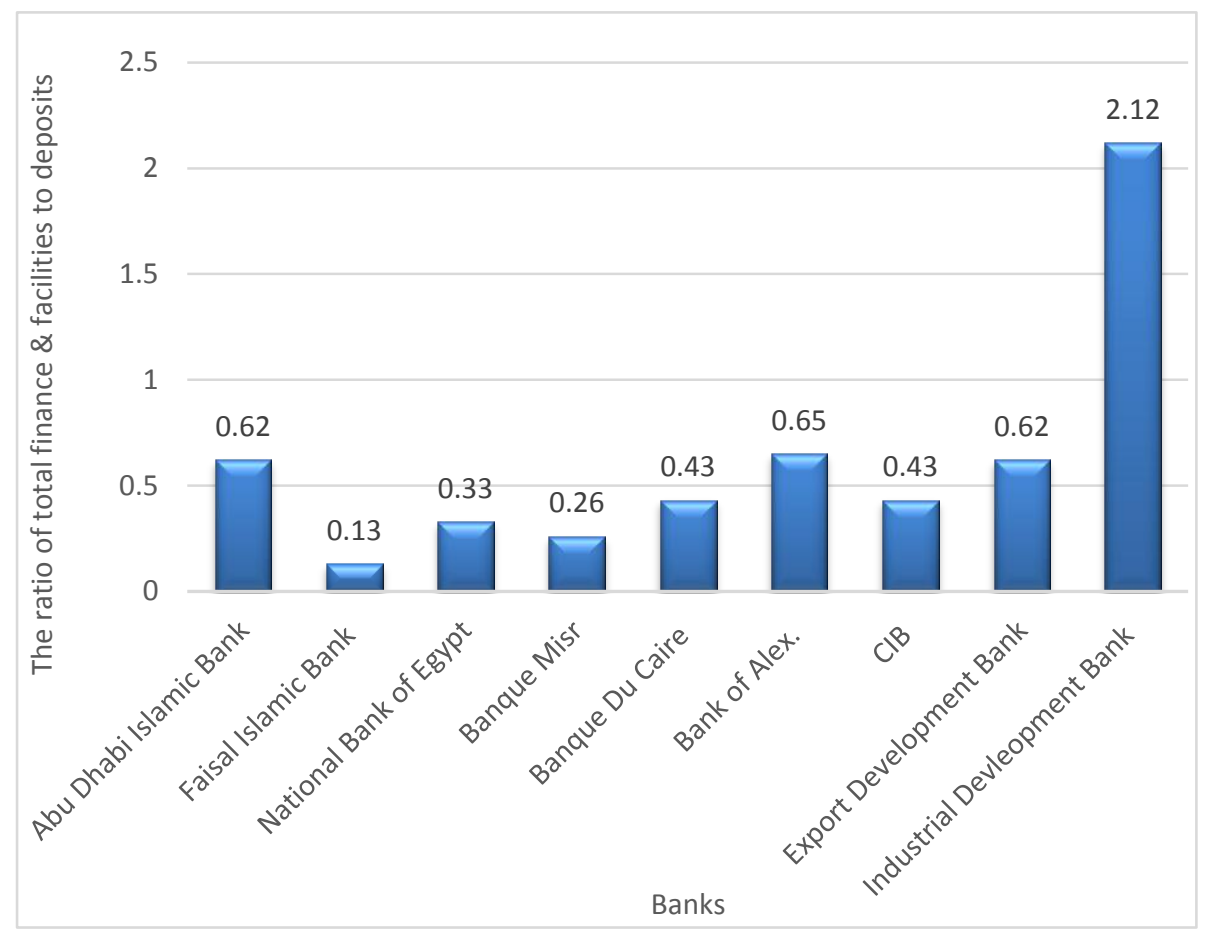

Figure 4. The ratio of total finance $\&$ facilities to deposits 


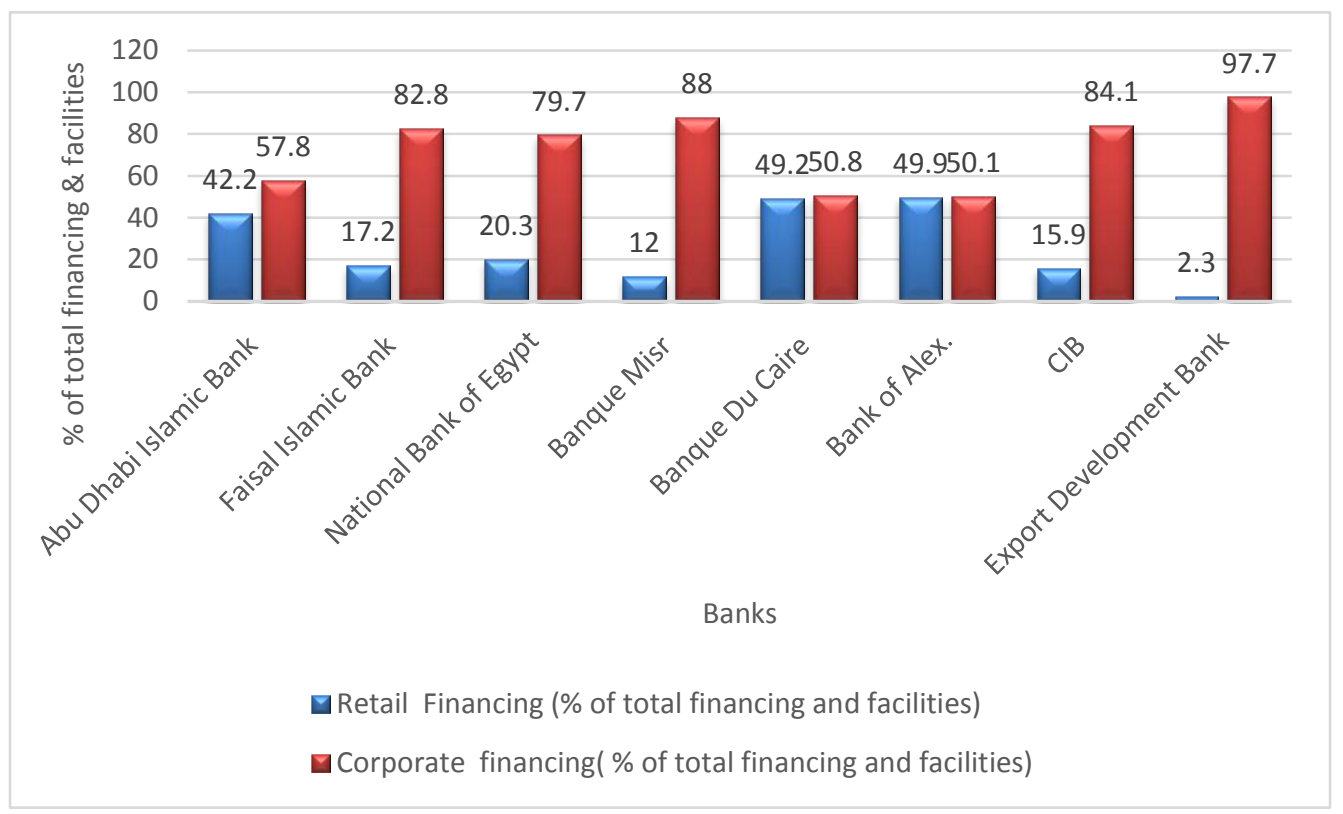

Figure 5. The Distribution of Financing \& Facilities between Retail and Corporate

To examine in more details the role of banks as financial intermediaries based on how much finance and facilities they provide, the structure of the finance and facilities provided by banks was investigated. Figure (5) shows the distribution of financing \& facilities between retail and corporate. As this figure illustrates, Faisal Islamic Bank prefers to finance corporate with $82.8 \%$ of its finance \& facilities goes to corporate finance which is higher than the sample mean of the commercial bank which is $70.5 \%$. For Abu Dhabi Islamic Bank, even though the percentage of its finance \& facilities that goes to corporate, which is $57.8 \%$, is less than the case of Faisal Islamic Bank and below the mean of the sample of all commercial banks, it still higher than this percentage for Banque Du Caire and Bank of Alexandria.

Fourth, the percentage of income from finance \& facilities of the total income.

As figure (6) shows, Faisal Islamic Bank is ranked the first among all commercial banks in the sample in terms of the ratio of its income received from finance \& facilities activities of its total income. This number is more than one standard deviation above the average of the sample of all commercial banks. Only 2.3\% of its income comes from fees and commissions. On the other side, Abu Dhabi Islamic Bank is ranked the last among all commercial banks in the sample with a percentage of $85.5 \%$ of its income source comes from the finance \& facilities activities. This percentage is more than one standard deviation below the average for the sample of all commercial banks. Meanwhile, the bank is ranked the highest among other commercial banks in terms of the percentage of the income that comes from fees and commissions.

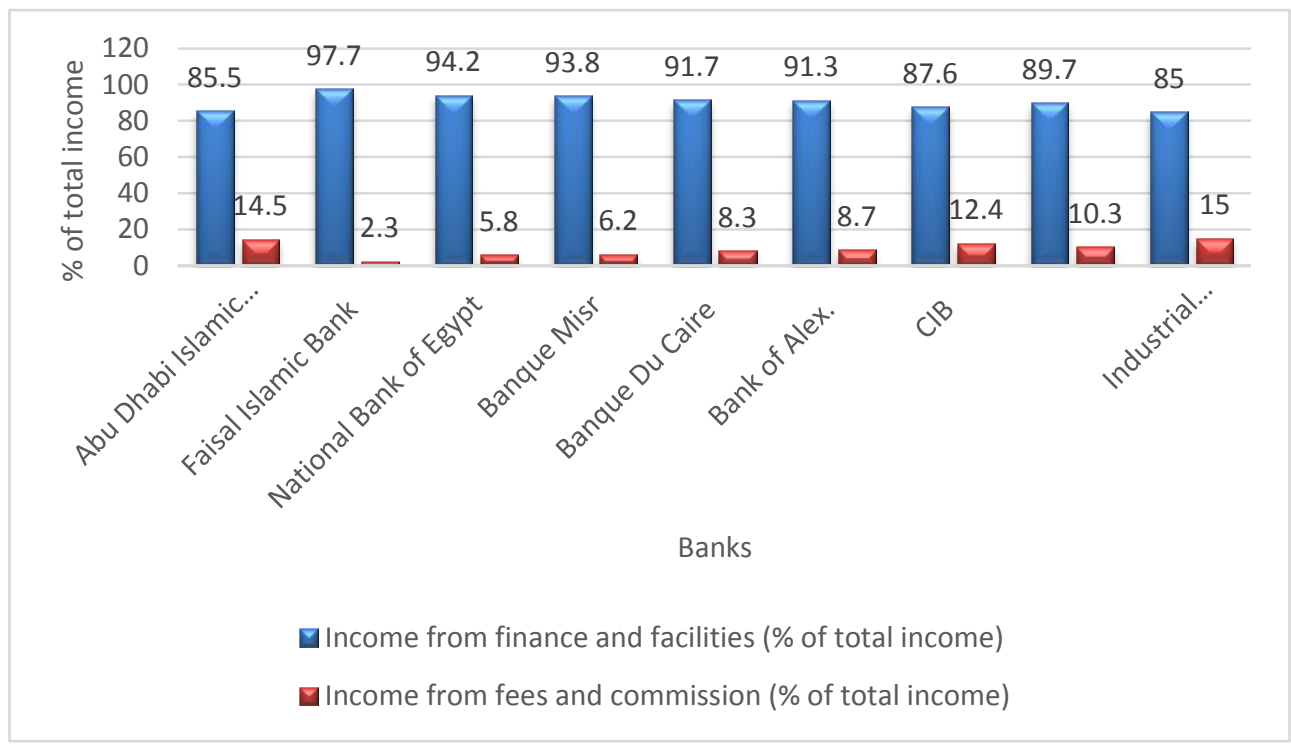

Figure 6. The distributions of income between finance \& facilities and fees\& commissions 


\subsection{The Role of Banks in Poverty Alleviation in Egypt.}

In order to assess the role of Islamic Banks in poverty alleviation in Egypt in comparison with other banks, I will examine to what extent Islamic Banks target the regions in which the poverty level is very high. All studies and data show that the poorest region in Egypt is Upper Egypt. Thus, I will examine to what extent Islamic Banks give an attention to Upper Egypt in their operations compared with conventional banks. In doing so, I will depend on two indicators as follows:

First, the percentage of retail finance to the Upper Egypt region.

As figure (7) shows, even though Abu Dhabi Islamic Bank has provided retail finance to Upper Egypt, as a percentage of its total retail finance, more than what has been provided by Faisal Islamic Bank. The percentages of retail Finance to Upper Egypt of the total retail finance is only 10.7\% and 3.6\% for Abu Dhabi Islamic Bank and Faisal Islamic Bank, respectively. However, it is worth mentioning that this indicator for Abu Dhabi Islamic Bank is higher than the CIB, which represents private foreign banks in Egypt and the third largest bank after the National Bank of Egypt and Banque Misr. We notice also that Bank of Alexandria, which is a privatized bank that owned by a foreign bank has the highest percentage of retail finance of total finance provided to the Upper Egypt region.

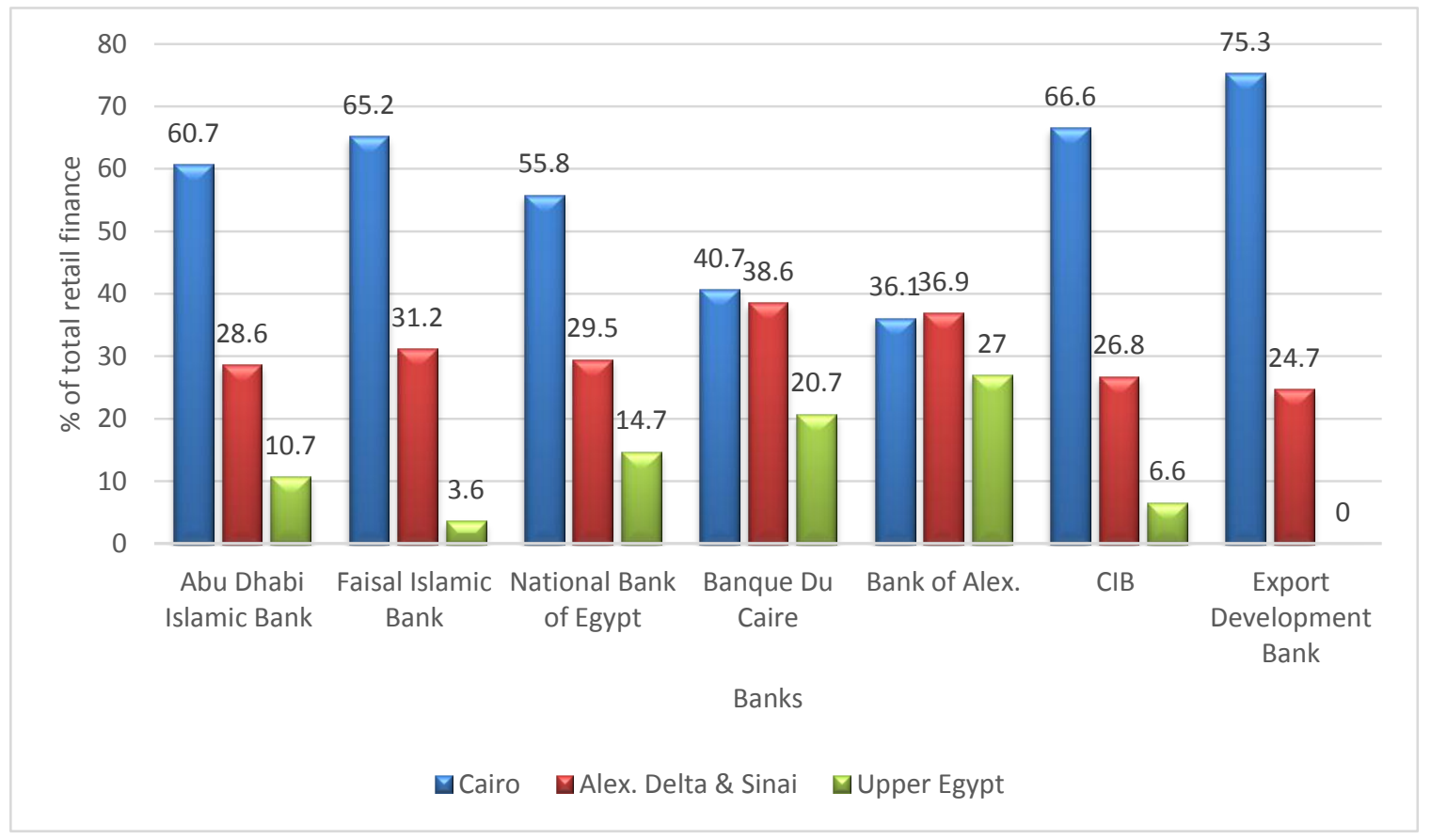

Figure 7. The Distribution of Retail Finance among Regions

Second, the percentage of corporate finance to the Upper Egypt region.

As figure (8) shows, Faisal Islamic Bank provides 1.5\% of its corporate finance to the Upper Egypt region. Even though this is a very low percentage, the bank is ranked higher than CIB. Moreover, the highest percentage of corporate finance is provided by Bank of Alexandria and it is $4.1 \%$. The average percentage of corporate finance to the Upper Egypt region among all banks in the sample is $1.5 \%$. Thus, we conclude that Faisal Islamic Bank did what other banks did in average in terms of allocating its finance to different region. Regarding Abu Dhabi Islamic Bank, the percentage of corporate finance to the Upper Egypt region is near zero. 


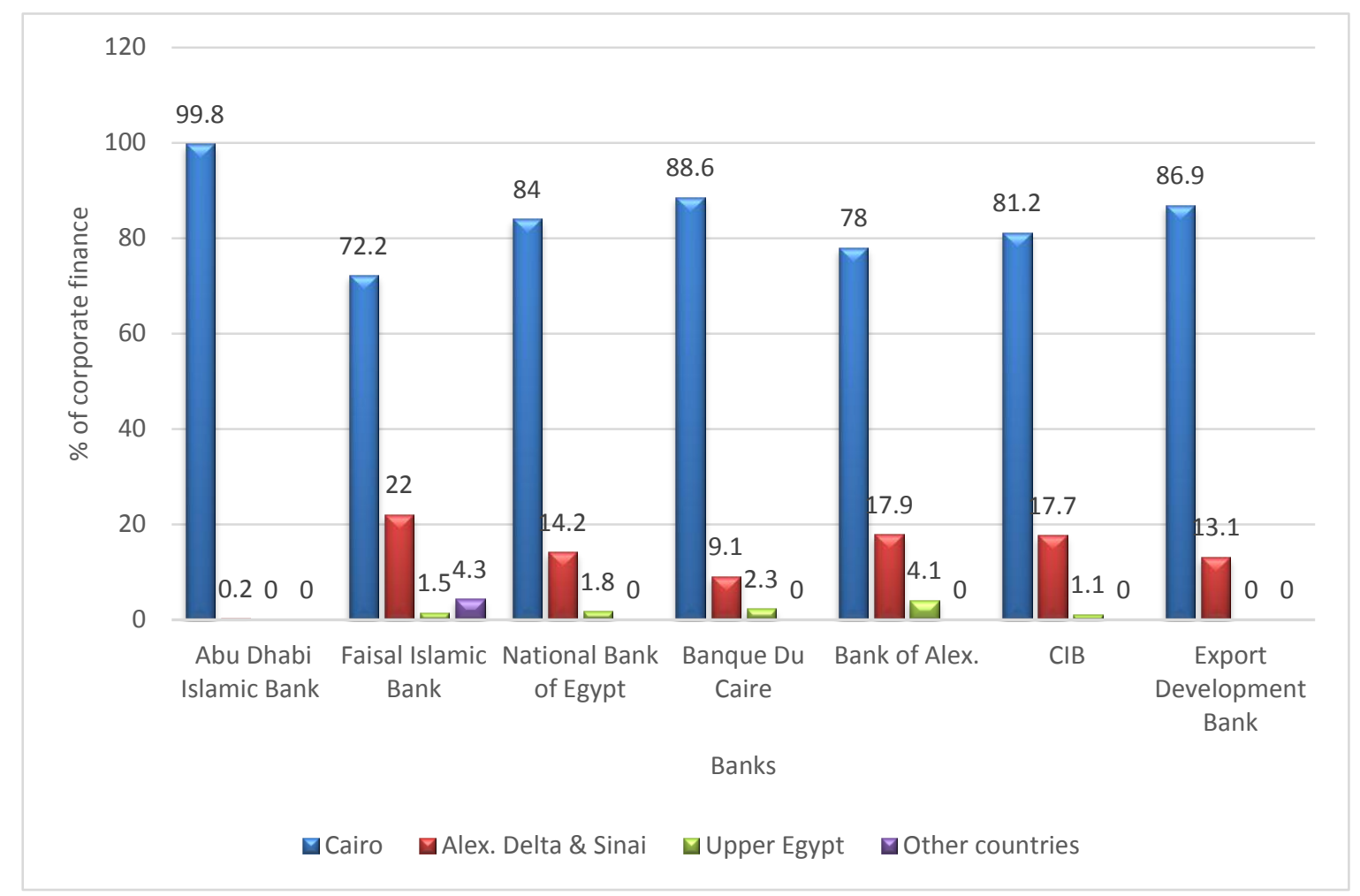

Figure 8. The Distribution of Corporate Finance among Regions

\section{Calculating the Intermediation for Development Index (IFDI)}

In this section I will use IFDI, the index introduced by Massoud (forthcoming), to investigate the role of Islamic banks as financial intermediaries that support development in Egypt compared with conventional banks. The index consists of four sub-indices as follows. The first sub-index is the Size Index (SI) which measures the size of a bank by its total assets and total deposits. The second sub-index is the Financial Intermediation Index (FII) which measures the function of a bank as a financial intermediary. FII is calculated by using the total finance $\&$ facilities as a percentage of total deposits and the income from finance and facilities as a percentage of the total income. The third sub-index is the Financial Orientation Index (FOI) which measures to what extent a bank is oriented to corporate vs. retail finance. FOI is calculated using the total corporate finance as a percentage of total finance and facilities. The fourth sub-index is the Regional Orientation Index (ROI) which measures to what extent a bank is oriented to provide finance to the poorest region in the country.

To calculate IFDI, I used the following equations and formulas.

1- Dimensional Indices (sub-indices) are calculated by the following equation:

Dimensional index $=($ actual Value - minimum value $) /($ maximum value - minimum value $)$

Table (1) shows a summary of maximum and minimum values for all the dimensional indices:

2- Combined SI and FII are calculated by the following equation:

Combined index $=\left\{\left(S U B I 1^{1 / 2} * S U B I 2^{1 / 2}-\operatorname{MinV}\right) /(\operatorname{OMaxV}-\mathrm{MinV})\right.$

While SUBI1, SUBI2, MinV, and OMaxV denote sub-index1, sub-index2, minimum value, and the observed maximum value, respectively.

3- The combined IFDI is calculated by the following equation:

$I F D I=\mathrm{SI}^{1 / 4} * \mathrm{FII}^{1 / 4} * \mathrm{FOI}^{1 / 4} * \mathrm{ROI}^{1 / 4}$

4- Ln values were used in calculating SI. 
Table 1. Summary of the values used in the calculations of the dimensional (sub) indices.

\begin{tabular}{|c|c|c|c|}
\hline Dimension / Indicator & Component & Maximum & Minimum \\
\hline \multirow[t]{4}{*}{ SI } & Total Assets & $727,786,756$ & 500,000 \\
\hline & (000’s L.E.) & $\begin{array}{l}\text { (the National Bank of } \\
\text { Egypt) }\end{array}$ & $\begin{array}{c}\text { (the minimum capital for } \\
\text { opening a new bank in Egypt) }\end{array}$ \\
\hline & Total Deposits & $360,188,995$ & $1,273,213$ \\
\hline & (000’s L.E.) & $\begin{array}{l}\text { (the National Bank of } \\
\text { Egypt) }\end{array}$ & (Industrial Development Bank) \\
\hline \multirow[t]{4}{*}{ FII } & Total Finance and Facilities & 65 & 13 \\
\hline & (\% of total deposits) & (Bank of Alex.) & (Faisal Islamic Bank) \\
\hline & Income from Finance and & 97.7 & 85 \\
\hline & Facilities ( $\%$ of total income) & (Faisal Islamic Bank) & (Industrial Development Bank) \\
\hline \multirow[t]{3}{*}{ FOI } & Finance and Facilities to & 97.7 & 50.1 \\
\hline & Corporates $(\%$ of total & (Export Development & (Bank of Alex.) \\
\hline & finance and facilities) & Bank) & \\
\hline \multirow[t]{2}{*}{ ROI } & Finance and Facilities to the & 15.6 & 1.8 \\
\hline & $\begin{array}{l}\text { Poorest Region ( } \% \text { of total } \\
\text { finance and facilities) }\end{array}$ & (Bank of Alex.) & (Faisal Islamic Bank) \\
\hline
\end{tabular}

Source: the author calculations.

The remainder of this section summarizes the calculation results of IFDI for all Islamic and conventional banks used in the sample. Table (2) shows that the two public banks are ranked at the top of the sample in terms of IFDI. As shown in this table, IFDI for Banque Misr and the National Bank of Egypt are 0,550 and 0.467, respectively. While Banque Du Caire is ranked the fourth with 0.175 of IFDI, slightly after the CIB which scores 0.181 of IFDI. The high scores for public banks is attributed to the high scores that these banks scored in both SI and FOI which can be explained by the historical reasons that made these banks are the oldest banks in Egypt. Another reason can help to explain the high scores for public banks is that government transactions only conducted through them. Central and local branches of government and the public sector firms are allowed to make financial transactions only with public banks. In addition to that, government usually direct public banks to provide special programs for supporting specific industries which increases the FOI scores for these banks. Even though Bank of Alexandria is ranked the sixth in terms of IFDI which is 0.094, it performs very well in terms of FII sub-index. However, we notice that the bank performance in terms of FII and ROI scores the first rank among all banks. Thus, its weak performance in the overall IFDI is attributed to its, relatively, small size measured by SI and the low FOI score it has. Regarding Islamic banks, their performance is very low. They were ranked the last and the fifth in terms of IFDIs which are as low as 0.017 and 0.157 for Faisal Islamic Bank and Abu Dhabi Islamic Bank, respectively. Regarding specialized banks, I could not calculate IFDI because of data shortage.

Table 2. IFDI and dimensional indices for Islamic and conventional banks in Egypt

\begin{tabular}{|c|c|c|c|c|c|c|}
\hline Bank / Index & SI & FII & FOI & ROI & IFDI & $\begin{array}{l}\text { IFDI } \\
\text { Rank }\end{array}$ \\
\hline Abu Dhabi Islamic Bank & 0.044 & 0.435 & 0.163 & 0.200 & 0.157 & 5 \\
\hline Faisal Islamic Bank & 0.115 & 0.001 & 0.686 & 0.001 & 0.017 & 7 \\
\hline National Bank of Egypt & 1 & 0.441 & 0.622 & 0.187 & 0.476 & 2 \\
\hline Banque Misr & 0.653 & 0.319 & 0.795 & $\mathrm{~N}^{*}$ & 0.550 & 1 \\
\hline Banque Du Caire & 0.154 & 0.562 & 0.015 & 0.964 & 0.175 & 3 \\
\hline Bank of Alexandria & 0.093 & 0.838 & 0.001 & 1 & 0.094 & 6 \\
\hline $\begin{array}{l}\text { Commercial International Bank } \\
\text { (CIB) }\end{array}$ & 0.336 & 0.455 & 0.714 & 0.010 & 0.181 & 4 \\
\hline Export Development Bank & 0.041 & 0.742 & 1 & $\mathrm{~N}$ & $\mathrm{~N}$ & $\mathbf{N}$ \\
\hline Industrial Development Bank & 0 & 0 & $\mathrm{~N}$ & $\mathrm{~N}$ & $\mathrm{~N}$ & $\mathbf{N}$ \\
\hline
\end{tabular}

Source: Author calculations

* IFDI for Banque Misr is calculated by the formula: IFDI = SI1/3 * FII1/3 * FOI1/3 because there is no data available to calculate ROI for it. 


\section{Conclusion and policy recommendations}

Islamic banking has been given an increasing attention since the global financial crisis of 2007/2008. Many studies found that Islamic banks were more resilience than conventional banks during and aftermath the crisis. While in theory, Islamic banking provides a plausible alternative for conventional banking, in practice it fails to do so. This failure can be attributed to two factors. First, the high level of operational and liquidity risks that exist in a pure Islamic banking. Second, Islamic banks have failed to provide a wide range of brand new facilities to their customers. Instead, what they are doing is providing the appropriate Islamic terminology for de facto conventional financial operations and products. The calculation of IFDI proves empirically that Islamic banking in practice does not provide an attractive alternative for conventional banking in Egypt. In a matter of fact, both Islamic banks in the sample preformed less than conventional banks, except for Bank of Alexandria. Thus, for Islamic banking to provide an attractive alternative for conventional banking: (1) it has to take some measures that make it close to the theory of Islamic banking in banks' operations and facilities, instead of just providing Islamic terminology for the existing conventional banking products. (2) Islamic banking's experts have to find out solutions for the difficulties that face Islamic banks while implementing a pure Islamic banking model. Examples of such difficulties are: operational \& liquidity risks, Competitiveness, and the level of expertise in the Islamic banking industry.

\section{References}

Ariss, R. T. (2010). Competitive conditions in Islamic and conventional banking: A global perspective. Review of Financial Economics, 19,101-108. http://dx.doi.org/10.1016/j.rfe.2010.03.002

Beck, T., Demirguc-Kunt, A., \& Merrouche, O. (2013). Islamic vs. conventional banking: Business model, efficiency and stability. Journal of Banking \& Finance, 37, 433-447. http://dx.doi.org/10.1016/j.jbankfin.2012.09.016

EY (2014). World Islamic Banking Competitiveness Report, 2013-2014.

Farooq, M., \& Zaheer, S. (2015). Are Islamic Banks More Resilient during Financial Panics? IMF Working Paper, $W P / 15 / 41$.

Hasan, M., \& Dridi, J. (2010). The Effects of the Global Crisis on Islamic and Conventional Banks: A Comparative Study. IMF working Paper, WP/10/201.

Islamic Financial Service Board (2013). Islamic Financial Services Industry Stability Report, 2013.

Ismail, A. G., Akbar, S., \& Ngalim, S. M. (2014). Measuring the Value of Islamic Banks. IRTI Working Paper Series, WP\# 1435-13.

Khan, F. (2010). How 'Islamic' is Islamic Banking? Journal of Economic Behavior \& Organization, 76, 805-820. http://dx.doi.org/10.1016/j.jebo.2010.09.015

Kassim, S. H., \& Abd. Majid, M. S. (2010). Impact of financial shocks on Islamic banks. International Journal of Islamic and Middle Eastern Finance and Management, 3(4), 291-305. http://dx.doi.org/10.1108/17538391011093243

Massoud, A. (2013). Financial Empowerment and Credit Accessibility: A Business Model for Poverty Alleviation in Egypt. Commercial Studies, XX, Faculty of Commerce, Sohag University, July, 2013.

\section{(cc) EY}

This work is licensed under a Creative Commons Attribution 3.0 License. 